\title{
Periodical Use and
}

\section{Collection Development}

Use statistics are a valuable decision-making tool, particularly in a collection that is primarily sci-tech, where high subscription costs demand periodicals be closely tied to current teaching and research needs. Unless a commercial circulation system is available, an in-house method of recording and tabulating use figures must be developed. This article gives an example of how use of periodicals in an academic environment has been recorded, how it has been built into a collection development program, and how it has focused on areas for future concern.

\section{C}

ALARKSON COLLEgE OF TECHNOLOGY is a private, four-year, coeducational institution with 215 faculty members and an enrollment of more than 3,000 undergraduate and approximately 250 graduate students. It offers five doctoral programs in science and engineering, and it provides comprehensive programs in management, the humanities, and the social sciences.

Clarkson's library staff consists of six professionally trained librarians, nine clerical personnel, and fifteen to twenty student assistants. Library holdings include nearly 90,000 books, periodical backfiles of 39,800 bound volumes $(5,000$ of which are in storage), 4,500 microfilm reels, and 430 volumes on microfiche.

Single subscriptions are held for $1,300 \mathrm{ti}$ tles, 100 of which are indexing and abstracting services. There are 2,150 noncurrent titles resulting from publication cessations, cancellations, and title changes. In addition,

Jacqueline A. Maxin is planning assistant/ information services, PPG Fiber Glass Technical Center, O'Hara Township, Pennsylvania, and a doctoral student in the Graduate School of Library and Information Sciences, University of Pittsburgh. This article is based on a paper presented by the author when she was on the library staff at Clarkson College of Technology, Potsdam, New York. The author expresses her thanks to Ottilie H. Rollins, head librarian, and David A. Sharpe, programmer and analyst, at Clarkson for their advice and assistance throughout the course of this survey. the library is a partial government depository and has more than 40,000 technical reports and approximately 65,000 NASA documents on microfiche.

\section{Periodical Use Survey}

Ninety percent of the Clarkson library's periodical budget is spent to meet everincreasing subscription costs for sci-tech periodicals. In order to obtain some quantitative data on which to base collection management decisions, a periodical use survey was begun in September 1974, which involved semiannual tabulations of data recorded on three-by-five-inch cards. ${ }^{1}$ Data collection was designed to provide information to aid in evaluating current and retrospective acquisitions, in developing commercial binding priorities, and in weeding. ${ }^{2}$

By December 1976 the periodical use survey had produced such extensive data that computerization was needed to maintain it effectively. A tab card was designed for direct entry of information, with further automated processing through use of mark sensing equipment. The card identifies a periodical by its International Standard Serial Number (ISSN) or by a locally assigned number if no ISSN is available. User category and quantity of material used by form (microforms, bound volumes, or loose issues) are also entered.

Periodical use figures are built into a master serials data base, from which additional listings may be obtained by any combination 
of eighteen fields of information. An example of the master serials printout obtained is shown in figure 1 .

The information fields include ISSNs, beginning and ending volumes and dates, degree of completeness, locations, subscription, vendor, payment, department, subject headings, microforms, binding, frequency, cross-reference codes, and retention. Use shown is by academic year, separating circulation by broad user categories and distinguishing in-library use by form, with qualifying statements where appropriate.

For the survey all circulating materials are recorded, including current issues of fifty mathematics and physics periodicals that are routed to an on-campus reading room. Although the number of different users cannot be identified, the type of use by Clarkson's patrons and circulation generated by townspeople and borrowers from neighboring colleges can be obtained.

Material sent to fill interlibrary loan requests is recorded, while incoming loan statistics are kept by the interlibrary loan staff. In-library use is included by requesting patrons to return microforms to the circulation desk for reshelving and by scanning library tables for bound volumes and loose issues. In-library use, however, can only be viewed as an estimate that does not indicate the nature or level of consultations. ${ }^{3}$

Although there are many studies regarding obsolescence in sci-tech literature, ${ }^{4,5}$ this survey did not record the date of material consulted. In order to support Clarkson's courses in the history of science and technology, periodical backfiles are maintained for student research, projects, and study, except where titles are used solely for current awareness purposes. To this end, physical form alone is distinguished, in an effort to separate demand for retrospective and current material.

\section{SURVEY Costs}

When using three-by-five-inch cards in the manual system, the circulation staff could record three transactions each minute. Semiannual tabulations by student assistants required ten hours, and composite listings called for additional time on the part of the serials staff. With use of tab cards only two transactions can be recorded each minute. However, tabulations and listings are now done on the computer, so the serials staff assists by processing all in-library and reserve room use figures.

Programming and keypunching are provided by Clarkson's Computing Center, which charges only for computer time and paper. In-library use data are collected by student assistants, a process that requires about thirty minutes each day and provides little information for the time spent.

The cost of maintaining a periodical use survey is justified by the confidence with which collection development decisions can be made. In reviewing titles for acquisitions, binding, and weeding, consideration is given to use, length and completeness of backfiles, bibliographic accessibility, and support for present and planned academic programs. Attention is also given to lists of periodicals needed to meet standards set by such accrediting bodies as the American Chemical Society and to lists recommended by such authorities as the American Institute of Biological Sciences.

\section{ACQUISITIONS}

Since the mid-1960s Clarkson's faculty has been able to add new subscriptions only if matched in cost by cancellations. This policy has kept the periodicals budget in check, and it has tailored current titles to curricular and research needs. To aid in selection, departmental printouts with subscription costs and holdings statements have been provided and now include use spanning four academic years.

Faculty members are encouraged to cancel unused titles or to build assignments around those that should be consulted. In view of new copyright legislation, no titles with multiple use are cancelled, and interlibrary loan transactions strengthen requests for new subscriptions. ${ }^{6}$ Depository, free, and gift periodicals are begun to complement the collection and are maintained only if used. Cumulative indexes and supplementary materials are purchased for heavily used titles, and incoming loan statistics are the basis for obtaining backfiles, in microform where available.

\section{BINDING}

Due to the high subscription costs of sci- 


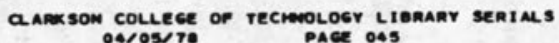

O3i700 ANAL YTICA CHIMICA ACTA

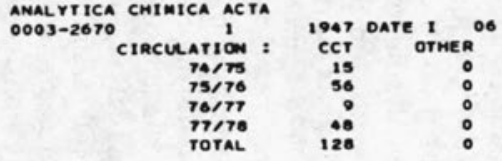

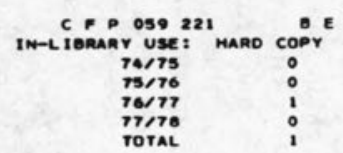

MICROFORM.

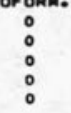

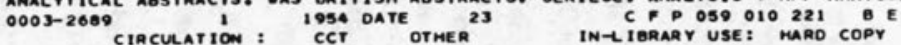

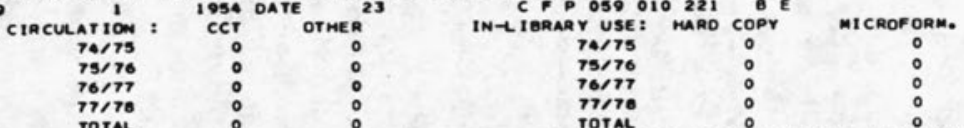

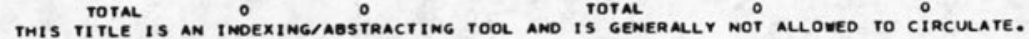

031900 ANM YTICN CHEMISTRY, WAS INOUSTRIAL C ENGINEERING CHEMISTRYYANALYTI CAL EDITION

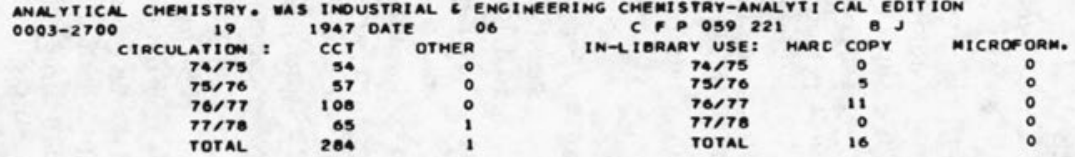

032000 ANORIOT. JOHN L. GUIOE TO US GOVERMIENT SEALALS P PERIOD. NOU GUIDE US PUBLICATIONS. R015.73.A573GU. THIS TITLE IS SHELVED IN THE BOOK COLLECTION ANO IS NOT INCLUDEO IN THE PERIODICNL USE SURVEY.

032100 ANGEUANOTE CMEMIE

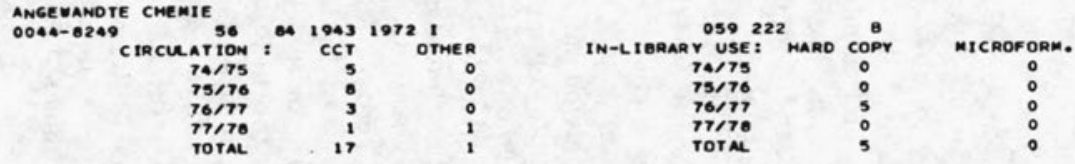

032200 ANGeUandte CHEMIE; INTERMATIONAL EOITION IN ENGL 1 SH.

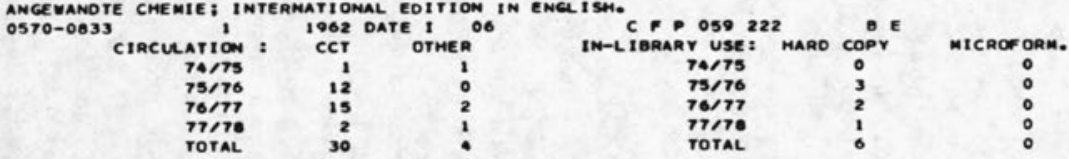

Fig. 1

Master Serials Printout 
ence and engineering periodicals, commercial binding has been selective so that funds can be freed for collection expansion. Priorities include indexing and abstracting journals, series classified and shelved in the book collection, and heavily used periodicals not available in microform.

Microforms are seen as a space saving alternative to binding and are considered for all used titles, except those with figures, formulas, and color illustrations, and particularly those whose size and format make binding difficult. Approximately $500 \mathrm{vol}-$ umes are commercially bound each year, and 180 current titles are received simultaneously on microfilm. To date, 10 percent of the periodical backfile collection has been converted to microfilm.

Temporary binding, using Bro Dart's Periodical Binding System Model 800, has been increased to include all other completed volumes. This system allows for inhouse binding by student assistants, with an average reshelve time of one day. At unit costs of eighty cents with covers and thirty cents without covers, temporary binding compares favorably with commercial costs of five dollars per volume. Order is brought to otherwise chaotic stacks without high investment in titles that may someday be withdrawn.

\section{WEEDING}

In 1973 the Clarkson library, as a member of the North Country Reference and Research Resources Council, added its holdings to the SUNY Union List of Serials data base, which comprises titles in the libraries of the seventy-two campuses of the State University of New York. The council, based in Canton, New York, serves to identify, share, and develop area resources and services and to further interlibrary cooperation and communication.

Entry into this data base permitted the production of several editions of the North Country Union List of Serials, a bibliographic instrument for the identification and location of titles within the council region, and to expedite the interlibrary transfer of materials for area patrons.

Entrance into the SUNY Union List of Serials, space considerations, and retention costs forced a total reexamination of the
Clarkson library's periodical collection. All unused titles with short and scattered holdings were withdrawn, as well as old and unbound titles that were not covered by indexing and abstracting journals. Since then periodicals have been continually reviewed so that shelf space is filled with used and potentially useful information.

To date 1,025 periodical titles have been withdrawn, 180 titles have been selected for limited retention, and 5,500 bound volumes and countless loose issues have been removed from the shelves. Weeded materials and issues replaced by microforms are offered for sale to backfile dealers, then to members of the Special Libraries Association's duplicate exchange program, to neighboring colleges where appropriate, and finally to the Universal Serials and Book Exchange. Items are shipped as requested, and unclaimed material is recycled.

\section{FUTURE CONCERNS}

Despite an intensive collection development program, more work can be done. A recent printout has ranked periodicals by total use and by density of use. An example of this printout is shown in figure 2. In this printout, periodicals, with asterisks indicating current subscriptions, are ranked by use spanning four academic years. Further breakdowns indicate use generated by Clarkson's patrons or use in the library and use generated by persons outside the Clarkson community. A cumulative percentage column indicates what percent of all use is met by how many titles. The length of each title's backfile is indicated; and by dividing a title's total use by length of its backfile, a relative density figure is obtained.

By comparing heavily used periodicals with interlibrary loan requests spanning the same time period, it has been possible to identify titles whose subscriptions were cancelled in error. To date fifteen such subscriptions have been resumed. Lengthy, unused titles are now grouped and may be cancelled in favor of other titles where use of backfiles and requests for current material have indicated a demonstrated need.

A cumulative percentage column shows that by housing the first twenty-five titles on the list, the library was able to satisfy just over 24 percent of the demand for peri- 


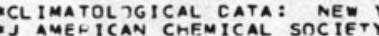

OS FLLID MECHANics

*STIENC

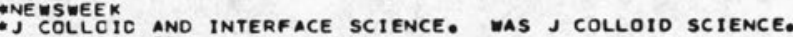
BUSINES MEEEK (AMMRICAN INSTITUTE CHEMICAL ENGINEERS)

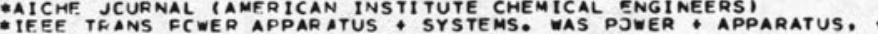
*ANALYTICAL CHEMISTRY. WAS INOUSTRIAL E ENGINEERING

OJ CHENICAL PHYS STCS

*US NEMS AND MORLD REPORT

echemical engineering science

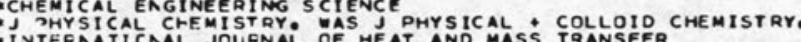

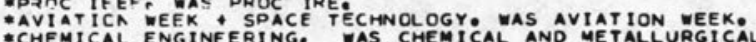

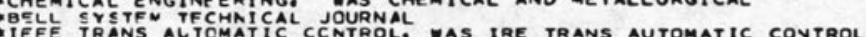

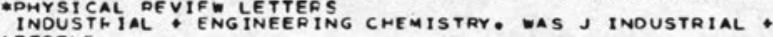

* PELPLE ENEFG

-j DRganic cremistar

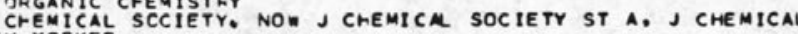

NEE YCFK TIMES

- INTERNATICNAL Journal CF SYSTEMS SCIENCE

PQOC FCYAL SOCIETY OF LONDON, SERIES A. MATH P PHYS SCIENCES. EFFLUEAT AND WA TER TRE ATMENT JOUFNaL

NEY YORK TA TEUNE

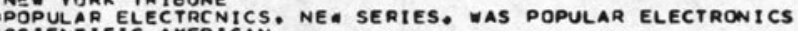

CCONSUMEF REACRTS

"Electricaics

*aPPLIED PHYSICS. WAS PHYSICS

*FOR日ES HAS AUOTO ENGINEERINC.

"CCMMERC GLSINESS DAILY

Fig. 2

Ranking by Use 
odical literature. In addition, 16 percent of all periodical titles accounted for 80 percent of all recorded and observed use. Seventy percent of all titles received use, as did 77 percent of all current subscriptions. There appears to be a positive correlation between periodicals recommended by accrediting and other authoritative bodies and heavy to moderate use.

Ranking by density of use has provided an additional grouping of titles, each of which requires different housing in accord with its demand. Although not an accurate figure in terms of use per year, density of use attempts to indicate those titles receiving the most concentrated use. Titles with high rank by use and low rank by density of use will be examined to determine whether retrospective (bound volumes and microforms) or current material (loose issues) was consulted. Such information will help determine whether backfiles should be purchased in microform, placed in storage, or withdrawn. Others areas of low or nonuse may indicate a need for bibliographic instruction or additional access tools.

With use statistics, current titles can be selected for display or reserve, and unused, noncurrent titles will again be reviewed for possible withdrawal. Departmental and subject printouts ranking titles by use will allow comparisons with other use and citation studies, ${ }^{7,8}$ and a citation analysis of Clarkson's theses may determine whether subscriptions in applicable subject areas should be lowered in favor of books. ${ }^{9}$
The Clarkson library and the libraries of the SUNY College at Potsdam, the SUNY Agricultural and Technical College at Canton, and St. Lawrence University in Canton comprise the cooperative acquisitions committee of the Associated Colleges of the St. Lawrence Valley. The Clarkson library specializes in science and engineering literature. It relies on the SUNY Agricultural and Technical College library for vocational materials and on the remaining two libraries for resources in the humanities and the social sciences. The SUNY College at Potsdam has a strong collection in the areas of art, education, and music, and St. Lawrence University has concentrations in such areas as geology and religion. With data collected by the Clarkson library's periodical use survey, titles with only or heavier nonClarkson use may be exchanged so that materials are located where optimum use might be expected.

\section{SUMMARY}

When combined with such factors as length and completeness of backfiles, bibliographic accessibility, support for present and planned academic programs, and recommendations by accrediting and other authoritative bodies, periodical use statistics can be a powerful decision-making tool. The Clarkson library's periodical use survey and its analysis will continue indefinitely so that operating funds can be maximized in meeting the ever-changing teaching and research needs of its faculty and students.

\section{REFERENCES}

1. Jacqueline A. Maxin, "Binding Selectively," Special Libraries 66:327-29 (July 1975); Jacqueline A. Maxin, "Weeding Journals with Informal Use Statistics," De-Acquisitions Librarian 1:9-11 (Summer 1976).

2. Maurice B. Line and Alexander Sandison, "Practical Interpretation of Citation and Library Use Studies," College \& Research Libraries 36:393-96 (Sept. 1975).

3. C. Harris, "A Comparison of Issues and InLibrary Use of Books," Aslib Proceedings 29:118-26 (March 1977).

4. Maurice B. Line, "The Half-Life of Periodical Literature: Apparent and Real Obsolescence," Journal of Documentation 26:46-52 (March 1970).

5. Alexander Sandison, "Densities of Use, and Absence of Obsolescence, in Physics Journals at MIT," Journal of the American Society for Information Science 25:172-78 (May-June 1974).

6. "Guidelines for the Proviso of Subsection 108 (g) (2)," as reprinted in Librarian's Guide to the New Copyright Law (Chicago: American Library Assn., 1977), appendix II, p.23-24.

7. Thomas J. Galvin and Allen Kent, "Use of a University Library Collection," Library Journal 102:2317-20 (Nov. 15, 1977).

8. Robert Goehlert, "Periodical Use in an Academic Library: a Study of Economists and Political Scientists," Special Libraries 69:51-60 (Feb. 1978).

9. Harry M. Kriz, "Subscriptions vs. Books in a Constant Dollar Budget," College \& Research Libraries 39:105-9 (March 1978). 